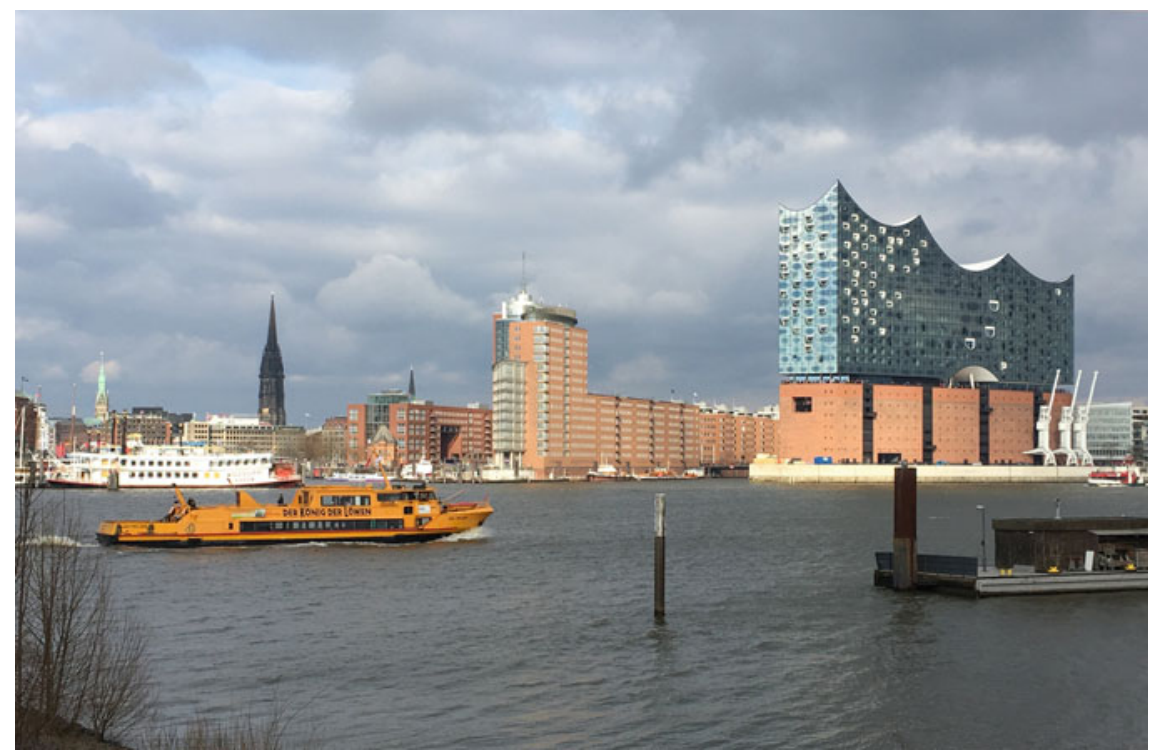

The HafenCity Hamburg, Germany with the Elbphilharmonie, 2018, Carola Hein, released under a Creative Commons Attribution-NonCommercial-NoDerivatives 4.0 International Licence 


\title{
Chapter 18 \\ The Impact of Planning Reform on Water-Related Heritage Values and on Recalling Collective Maritime Identity of Port Cities: The Case of Rotterdam
}

\section{Azadeh Arjomand Kermani, Wout van der Toorn Vrijthoff and Arash Salek}

\begin{abstract}
This chapter explores two structural aspects of port-city interaction. First, it studies the evolution of planning policies on post-industrial waterfront spaces in the Netherlands before and after the 2008 financial crisis, focusing on the former shipbuilding company Rotterdamsche Droogdok Maatschappij (RDM). The RDM site in Rotterdam is a significant part of the old port area, and its submarine and shipbuilding legacy has always been present in the heads and hearts of the citizens. Second, the chapter explores how reawakening the nautical culture and marine traditions in Rotterdam can also reanimate the historical links between port and city. It briefly analyses the goals, achievements, and effects of a few heritage projects on the port-city interaction and the maritime identity of this global port-city.
\end{abstract}

Keywords Water-related heritage $\cdot$ City-port interaction $\cdot$ City Ports Rotterdam • Maritime identity $\cdot$ Waterfront regeneration

\section{Introduction}

Bodies of water are an important foundation for economic development, and they facilitate the movement of goods and people around the world; thus, they are a vehicle for globalization (Hein 2016). People have long used water in ways beyond transportation, particularly for leisure and to construct local identities and imagery. Ocean coastlines throughout the world were (re)designed over centuries to create working waterfronts and ports, and cities along them connected water and land.

\footnotetext{
A. A. Kermani $(\varangle) \cdot$ W. van der Toorn Vrijthoff

Delft University of Technology, Delft, The Netherlands

e-mail: a.arjomandkermani@tudelft.nI

W. van der Toorn Vrijthoff

e-mail: W.vanderToornVrijthoff@tudelft.nl

\author{
A. Salek \\ Rotterdam Municipality, Rotterdam, The Netherlands \\ e-mail: a.salek@ rotterdam.nl


In the second half of the twentieth century, ports turned their backs on cities and created geographical barriers between cities and water (Hoyle 2000). They started to develop outside the limits of cities to accommodate larger ships. They abandoned urban waterfronts for deeper water harbours further away from settlements, creating "non-place" areas in the city (Norcliffe et al. 1996, p 126), and they also made ports and their activities disappear from the sight and minds of citizens. Many elements of the established institutional structure of these cities (harbour police forces, insurance companies, tax organizations, etc.) vanished; meanwhile, cities' income from transport- and port-related industries and services radically dropped. In response, urban governments and planners redefined their urban capacities: they no longer identified as port cities, but as urban hubs for various branches of the modern economy like tourism, service, trade and manufacturing. (Ducruet et al. 2009, 112 \& 55).

The dissociation of the port from the city has made their respective fates less and less dependent on each other, which has had significant socio-economic and political consequences. The challenging problem of how to deal with the vacated space in the heart of port cities around the world resulted in waterfront redevelopment programs within inner city regeneration plans (Desfor et al. 2010; Hoyle et al. 1994; Marshall 2001; Smith and Ferrari 2012). The regeneration of urban waterfronts became a wellestablished phenomenon in North America in the 1970s and spread to Europe city ports in the 1980s (Bone et al. 1997; Breen and Rigby 1996; Brown 2009; Schubert 2009; Ward 2006).

This chapter explores two aspects of urban life that are structurally involved in port-city interaction. First, it studies the evolution of planning policies on postindustrial waterfront spaces in the Netherlands before and after the financial crisis (2008), focusing on the former shipbuilding company Rotterdamsche Droogdok Maatschappij (RDM). The RDM site is a significant part of the old port area in Rotterdam, and its submarine and shipbuilding legacy has always been present in heads and hearts of the citizens. Second, this chapter explores how reawakening nautical culture and marine traditions can also reanimate the historical links between port and city. Focusing on a few heritage projects in the city of Rotterdam, this chapter briefly analyses their goals, achievements and effects on port-city interactions and the maritime identity of this global port-city.

\section{The Urban Identity of Port Cities}

Each port city has a distinctive urban identity that shapes how the port and the city interact (Lee 1998). Over the course of centuries, economic, social, environmental and cultural actors and networks interacted and produced urban life, institutional constellations and infrastructure (Warsewa 2011; Schubert 1994; Hein 2011, 178). The maritime identity of each port-city also formed in response to different stages of urban development and of seafaring and transport/trade-related urban strategies and policies (Boelens 2009, 62). Local and guest cultures, traditions and habits, all 
affect the spatial identity of the port cities. Therefore, the waterfronts and harbours represent the collective sense of memories and identity (Ple $\beta$ ka 2014, 144). Along with port hardware and infrastructure, other elements of collective memory-music, movies, texts, ceremonies - represent the culture and identity of each port city.

In fact, maritime culture historically has been established not just in physical objects but also in the collective memory of citizens through maritime traditions and ceremonies of nautical culture. Water-related values are hidden not only in the in their physical attributes but also in the cognitive interpretation of the port cities. Therefore in many situations, language, literature, food, film, photography and music may play a larger role than architecture and urban infrastructure in forming and representing the maritime identity of each port city. (Assmann and Czaplicka 1995, 129). Previously, the representation of the port city in the media conveyed the special sense of time and locality of casual seaman labour, jazz and pop music and migration, along with more negative portrayals of drugs and human trafficking and organized crime (Mah 2014, 10).

As the port detached from the city, the image of the port-city and the familiar stereotypes of harbours and waterfronts of earlier times-the longshoremen with colourful language, the containers and the working cranes-disappeared from urban spaces (Winslow 1998, 14). These changes mobilized networks of citizens, heritage organizations, artists and media to protect the dimming maritime feeling of urban spaces and the nautical legacy of harbour areas (Dündar et al. 2014, prologue). Over the last three decades, local communities have become more aware of the need to protect authenticity and water-related heritage, and public enthusiasm and civic participation in regenerating elements of nautical culture have increased (Feyen et al 2008; Stocker and Kennedy 2009).

Today, the governments of many port cities, in cooperation with several NGOs and private organizations, have set up new institutions to safeguard maritime heritage and protect naval customs. Some famous examples are the Association of European Maritime Heritage, the Maritime Heritage Association of Australia and the Scottish Maritime Heritage Association (Smith et al. 2015, 414). These institutions safeguard tangible maritime heritage in maritime museums and intangible heritage in seaport festivals, cultural excursions and historic sightseeing, paintings and postage stamps (Jinliang 2012, 47; OECD 2014, 136; Alegret et al. 2014).

\section{Port and City Interrelation in Rotterdam}

Over the centuries, the port and the city of Rotterdam have experienced a range of interrelationship patterns, from total interdependency up to spatial and strategic detachment (Meyer 1996; Boelens 2009). For most of that time, the port and the city were indistinguishable from each other. Rotterdam's waterfronts and harbours were located in the heart of the city or its nearby peripheries. Rotterdam's docks and harbours were not only port-city infrastructure, but they were also the site of commercial interactions between the city and the rest of the world (de Goey et al. 
2004). Major port development here started in the nineteenth century, due to evolving maritime technologies and improvements in cargo handling systems; new small quays adjacent to the city centre reached to the sea. World War II seriously damaged the port and its infrastructure, including some main warehouses and crane facilities. But the port quickly grew to the west in the 1950s and after; the construction of the Botlek and Europoort areas came at the cost of the destruction of some villages and nature reserves. During the 1970s, the port of Europoort and the Maasvlakte was developed $20 \mathrm{~km}$ out of Rotterdam by reclaiming land from the North Sea, becoming one of the biggest harbour facilities in the world.

In the early 1980s, port activities including businesses and industries moved tens of kilometres away to new lands rising from the North Sea, dubbed Maasvlakte II. Some prominent parts of the social structure of the port city-seamen, sailors, shipbuilders-disappeared from urban society (Steenhuis-Meurs 2009; Stouten 2010).

\section{Reinvention of the Seaport Identity of Rotterdam}

Soon after, the negative consequences of the outward movement of the port came to the attention of municipal authorities. The municipality was responsible for both urban and port development, and the city council had always invested heavily in the expansion of the port; the urban area and port facilities were closely interlinked, as officials believed that the success of the port would make Rotterdam a big city. But with the removal of the port to a site distant from the city, the vacant former port facilities stood as spatial barriers between the city centre and the Maas River, while the river itself literally divided the city into a rich north bank and a poor south bank.

From 1981, the city of Rotterdam was involved in an urban renewal project (stadsvernieuwing), in which it redeveloped historic waterfronts and port infrastructure in the urban core, and made some neoliberal changes in the socioeconomic structure of the city (Ministry of Economy 2009). These transformations considerably altered Rotterdam's identity. When the port physically and culturally left the city, maritime institutions waned in importance of the identity of the port city. Today, the port of Rotterdam is facing an image problem, or rather, the lack of any image and like many port-cities across the world, it is looking for ways to evaluate water-related heritage to build a resilient and competitive port-city relationship (Aarts et al. 2012). In recent decades, the municipality of Rotterdam has invested tens of millions of euros to reinvent and memorialize Rotterdam's maritime identity and to recover the mutual relationship between the city and the port to make the faded image of the port vivid once more. 


\section{Turn in Rotterdam's Urban Policies}

In order to create a common urban identity for city inhabitants, the port and the city had to foster new mutual benefits. Both were willing to invest in innovative solutions for decreasing urban congestion, increasing mobility issues, diversifying the economy and developing housing. The Rotterdam administration courted private investments and slowly changed from supply-led urban planners to developmentled facilitators (Wigmans 1998). After the energy crises of the 1970s, Rotterdam shifted from a social housing structure to more liberal housing policies (Mak and Stouten 2014, 1). By the end of the 1980s, Rotterdam's urban policies had taken an entrepreneurial turn. This so-called first wave of waterfront programs saw the abandoned port areas near the city centre as an excellent opportunity to rethink the identity of the city. The municipality prepared a large-scale master plan which recognized the River Maas as "the DNA of the city" (Aarts et al. 2012, p 13).

The regeneration of vacant harbour zones inside the urban core of Rotterdam (Fig. 1) started with the transformation of the Oude Haven (Old Port) into new quality housing areas. Soon it expanded to other areas near the city centre, more specifically the Leuvehaven (Fig. 2) Wijnhaven and Zalmhaven neighbourhoods into commercial and office areas. Later, the Scheepvaartkwartier and Parkhaven, a harbour zone and light industry zone, were turned into a tourist resort and high-quality residential areas. With the Kop van Zuid project, Rotterdam developed a new central business district on the south bank of the River Maas. The expansion of the metro line to the other side of the river and the construction of the monumental Erasmus Bridge in 1996 also gave the Kop van Zuid project national and international publicity, even though most of the initial office spaces had to be changed to residences due to the lack of market interest (Fig. 3).

In 2002, planners from the Municipal Department of Economy, Port, and Environment (Economie, Haven en Milieu) were drafting a promotional report, Port Vision 2020 (Havenplan 2020). International study trips to the port cities of Hamburg and London inspired them with a new vision of the port, which included three significant decisions: expanding the port (Maasvlakte 2), incorporating the port authority and developing the Stadshavens (City Ports) area. The port of Rotterdam wanted to improve its position as the smartest and most sustainable port in Europe; at the same time, city authorities wanted to strengthen the profile of the area by diversifying the economy with new sectors. Space has been created to develop new activities important to both the city and the port (Aarts et al. 2012) in the approximately 1600 ha area in the periphery. Here, inside the city's highway ring, port activities had animated the waterfront in the twentieth century; some port areas remained. The area included in the second phase of the Stadshavens project were Merwehaven and Vierhaven on the north side of the Maas River; Waalhaven, Eemhaven and the RDM campus on the south bank; and Rijnhaven and Maashaven on the eastern part of the plan (Fig. 4).

The Rotterdam Stadshavens Development Company (Ontwikkelingsmaatschappij Stadshavens Rotterdam) was established later that year as a new incorporated organization to initiate, facilitate and stimulate the transformation of vacant port industrial 


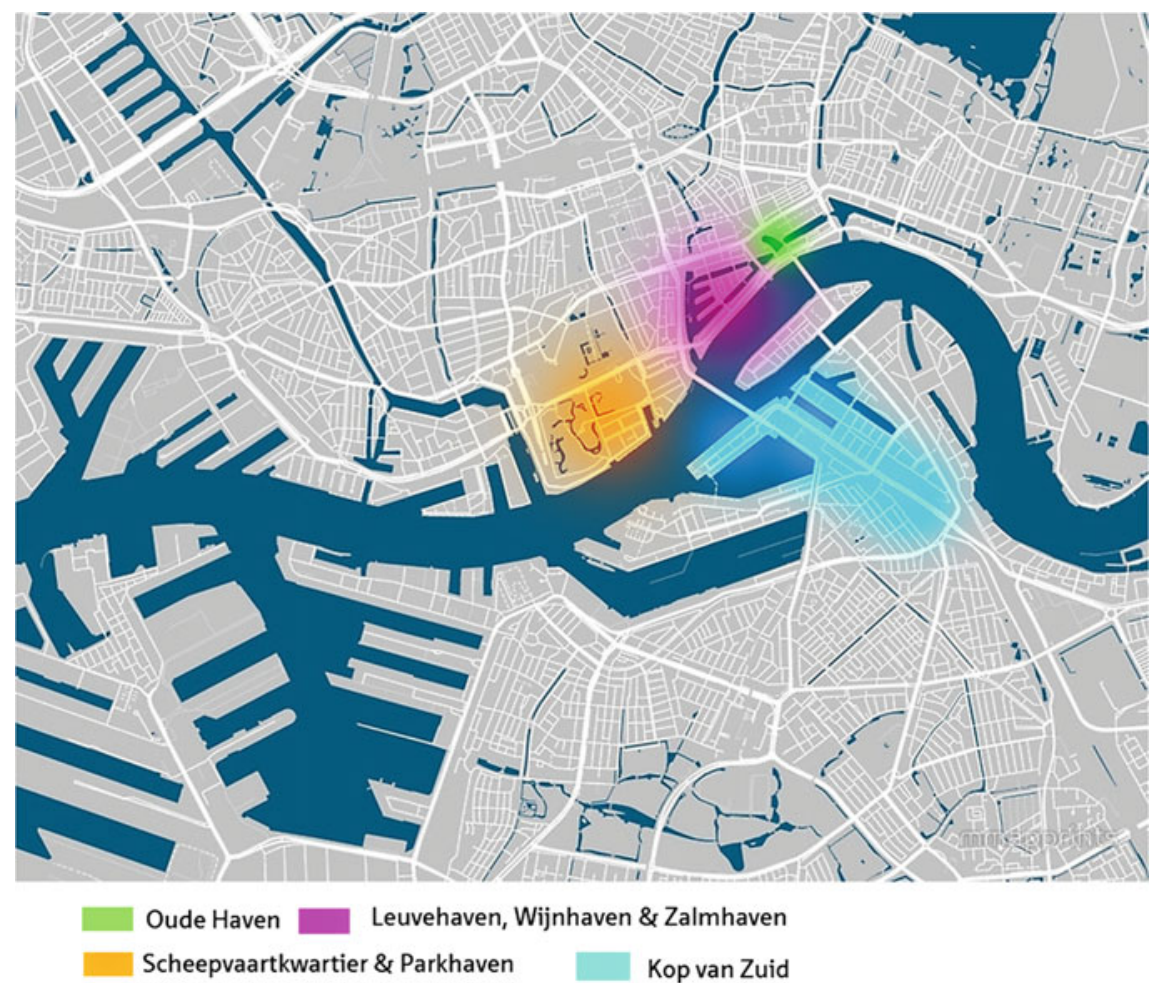

Fig. 1 First wave of waterfront regeneration programmes in Rotterdam, credit Azadeh Arjomand Kermani; released under a Creative Commons Attribution-NonCommercial-NoDerivatives 4.0 International Licence

areas in the west and south-western parts of the city into urban living and working areas by realizing a vision and a plan for their future spatial arrangement (Daamen 2010). In addition, the Company planned an expert seminar for early January 2004 to discuss the added value and potential of the conservation, adjustment, and reuse of the port landscape in the CityPorts area. The CityPorts Company moved its new headquarters to the former office of the Rotterdam Dry-dock Company (Rotterdamse Droogdok Maatschappij) in the heart of the CityPorts area.

In May 2005, the CityPorts Company published the Rotterdam CityPorts Development Strategy, a plan for the future spatial claims of the city and the port. The document gave an outline of intended changes in the plan areas of Stadshavens, including concrete plans for several locations (OMSR 2005). The strategy focused on the economic renewal of the area with the concept of harbour out/city in, transforming monofunctional areas within the Stadshaven into urban living environments (Structuurvisie-Stadshavens Rotterdam 2011). It valued the water and harbour infrastructure as an attraction for leisure-related activities and urban development, similar to previous waterfront redevelopments in Rotterdam. Moreover, it integrated water- 


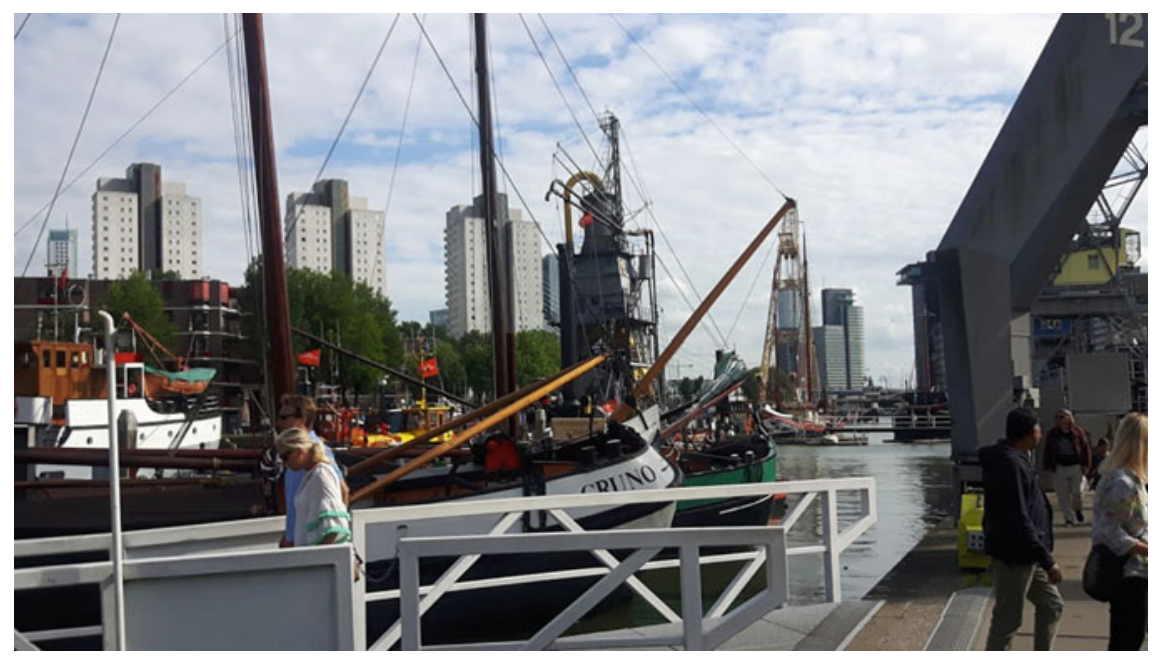

Fig. 2 Rotterdam Leuvehaven, 2017, credit Arash Salek; released under a Creative Commons Attribution-NonCommercial-NoDerivatives 4.0 International Licence

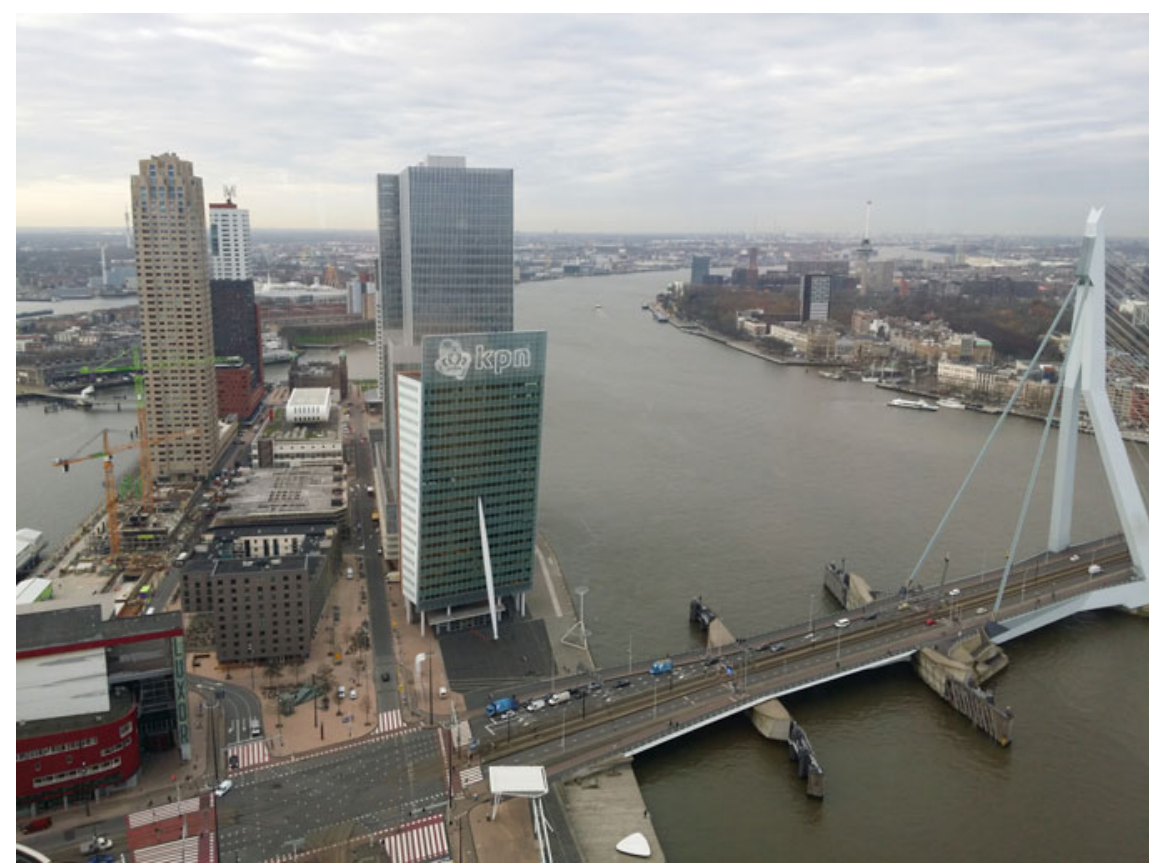

Fig. 3 View towards Kop van Zuid and the Erasmus bridge, credit Arash Salek; released under a Creative Commons Attribution-NonCommercial-NoDerivatives 4.0 International Licence 


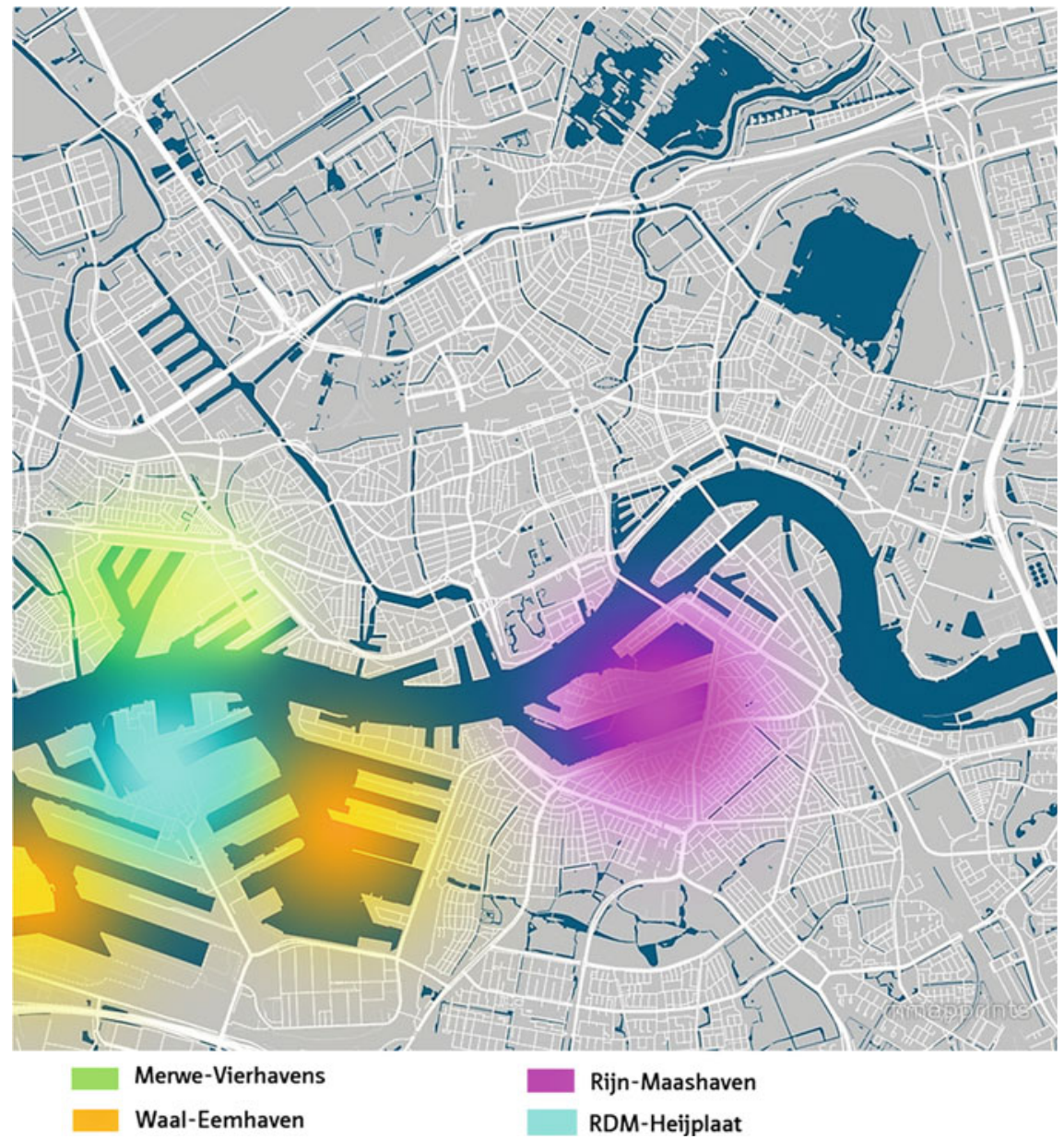

Fig. 4 Second wave of waterfront regeneration program in Rotterdam (Stadshavens area), credit Azadeh Arjomand Kermani; released under a Creative Commons Attribution-NonCommercialNoDerivatives 4.0 International Licence

related heritage and remnants of port activities into these developments because they are the historic identity of the Rotterdam harbour.

\section{Cruise Ship Tourism as an Instrument of Representing the Maritime Image of a Port City}

Yet another approach to revitalizing traditional waterfronts and to re-establish the missing link (Hein and Hillmann 2016) was the reintroduction cruise ships to the 
centre of Rotterdam. From 1873 to mid-1970, the Wilhelminakade in Rotterdam had been the home of the Holland America Line (HAL). During this period, many steam ships, like the famous "De Rotterdam", "De Nieuw Amsterdam" and "De Statendam", took thousands of passengers from Rotterdam to faraway places. The current Hotel New York was originally the headquarters of the HAL and its passenger terminal. During this period, many liners were operating between the Netherlands and North America and were instrumental transporting more than half a million immigrants from Europe to North America. In the second half of the twentieth century, because of the rapid growth of air transportation, especially the introduction of transatlantic jet air travel, the prominent image of passenger ships and liners disappeared from the Wilhelminakade. In the 1980s, the HAL moved its headquarters from Wilhelminakade to Seattle, and the city lost its dominant position as a global hub of passenger transportation.

This image changed in recent years with the development of cruise travelling (Financieele dagblad 3 May 2016). Since 2008, the European market for cruise travelling has grown by $49 \%$. In the late 1990 s, the Wilhelmina pier, the historic pier of the Holland America line and its huge passenger terminal building, were owned by the City of Rotterdam. In 2013, the Port and the municipality of Rotterdam invested almost 7 million euros into modernizing the monumental building into Cruise Terminal Rotterdam to bring the water back into the minds and hearts of Rotterdammers and to turn the downtown of Rotterdam into a living and leisure urban area (Rotterdam's City Vision 2030). The renovation was partly motivated by the demands of the cruise industry and tourism organizations, which wanted to double the number of cruise ship arrivals from 28 to 60 per year (Schipper 2010, 65). In May 2016, the Financieel Dagblad [Financial Daily] wrote, "The presence of the cruise ships in Rotterdam is good for the port and city imaging; however, for inventing this image, the municipality had to spend lots of money". In his speech at the opening of the renovated cruise terminal, the mayor of Rotterdam, Ahmad Aboutaleb, said that the cruise terminal is a good vehicle for connecting the port and the city and a very beneficial tool for the urban economy. He added that the main reason for investing in a new cruise terminal was to reattach the city to the port and to keep Rotterdammers connected to the port even if it is gone (Trouw 9 July 2015) Today, huge cruise liners enter Rotterdam (Kop van Zuid) from the North Sea to navigate their way down the Maas River through the central business district to the recently renovated International Cruise terminal on the Wilhelmina pier (Fig. 5).

The cruise liners are the remaining image of port activity. They keep the port image in the urban space and memorialize the nostalgic image of port experience. Each week, the once-abandoned waterfronts in the Kop van Zuid area are again full of maritime life and nautical events. While the cruise economy seeks to make best use of the remaining port infrastructure in downtown Rotterdam, the city presents its less discovered tangible and intangible seaport values, local self-image, and cultural identity to the outside world. 


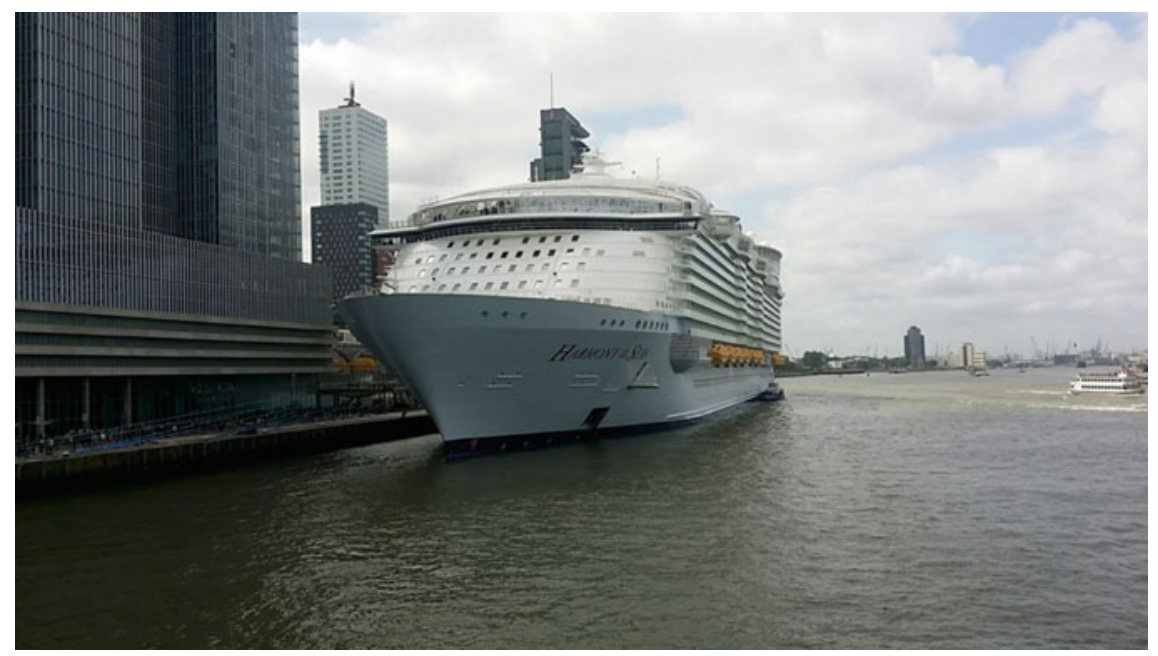

Fig. 5 Arrival of the Harmony of the Seas (the second largest passenger ship in the world) into the cruise terminal Rotterdam on 24 May 2016, credit Arash Salek; released under a Creative Commons Attribution-NonCommercial-NoDerivatives 4.0 International Licence

\section{The Redevelopment of RDM Terrain}

The Rotterdamsche Droogdok Maatschappij (RDM) shipyard has a long history in the shipbuilding industry. It was founded on the south bank of the Nieuwe Maas in 1902 as a continuation of an older shipyard, Maatschappij De Maas (Crimson 2005). As it gradually flourished, the work force grew and RDM authorities started building housing for the workers; the first development was a 1914 garden village, Heijplaat, which comprised 500 dwellings, 3 churches and other public facilities such as shops, parks and sports fields (Vries 2014). By the Second World War, the area had grown to 40 ha and became one of the largest shipyards in Europe. One ship built there between 1955 and 1959 was the ocean liner SS-Rotterdam of the Holland America Line (Crimson 2005). In these prosperous times, RDM wharf employed some 5000 people and therefore added a new housing district: "Het Nieuwe Dorp" (The New Village).

Until the year 2002, the Port of Rotterdam Company is a municipal organization. During the 1980s, the urban management and services of the RDM shipyard and the harbour zones on the south bank of the Maas River were transferred to the port companies. However, many ex-harbour areas in the north bank of Mass River remained part of the city.

After various mergers, the company was taken over by the Rijn Schelde Verolme $(R S V)$ Company and the village of Heijplaat was sold to the Woonbron housing corporation in late 1980s. In 1996, shipbuilding ended at the Heijplaat, and submarine maintenance and servicing ended in 1999. 
In the early years of the new millennium, the Heijplaat was a partly vacant and relatively barricaded urban district of Rotterdam. At that time, the municipality together with the port-company of Rotterdam and the local housing corporation (Woonbron) realized the imperative need for renovation and redevelopment of this district. In collaboration with the University of Applied Science Rotterdam (which at that time was running short of educational space), the City, Port Company and Woonbron established an organization for redeveloping the Heijplaat. This organization would implement plans and strategies for a sustainable urban district in Heijplaat in combination with an educational campus and a high-tech business complex for start-ups. The renovated head office of the old $R D M$ shipyard became well-known as an investment prospect in Rotterdam by the summer of 2005. Its buildings, its raw port industrial surroundings and the neighbouring garden village Heijplaat attracted interest from a variety of visitors. Along with those working on the CityPorts project or related tasks, both the Rotterdam University of Applied Science (Hogeschool Rotterdam) and the Albeda (Technical) College were looking for expansion space as well as connections with businesses. Representatives from Woonbron were looking for opportunities to create high-value living and working spaces. Inspired by notions such as open innovation and informal communities, and by field visits to other renovated historical industrial sites (such as the Zollverein in Essen), city planners formed the RDM Campus as a primary component in the revival of the CityPorts area. The RDM Campus connects research, multi-level education (vocational and higher level), and business - the "golden triangle"-by clustering start-ups, educational institutions, and research firms on the former RDM shipyard. The port authority supported the project: although the campus concept is a new approach and outside of its core business, it addressed the shortage of specialized technical workers and promised to attract other tenants to the area.

Even though the renewal of the Heijplaat was limited to refurbishing existing housing stock, especially rental housing, and new construction targeting higher income groups, Woonbron envisioned the RDM Campus as a hub for renewal, increasing the number of shops and other activity in the village to a critical mass (van Tuijl and Otgaar 2016). In addition, educational institutions and firms at the RDM Campus could also use the village. One example is Concept House Village, a number of houses where temporary users can test all kinds of new living concepts while the Institute of Concept House Construction and management CHIBB, monitors them and their inhabitants in order to analyse their reactions and adapt the technology accordingly.

The RDM development was a joint venture and a public-private partnership with formal partners as key players (educational institutions, Port Authority Rotterdam and Woonbron housing association) playing outside their core business. None of them had experience in large-scale integrated urban development and they all faced new challenges, including persuading others in Rotterdam to support the project and learning integrated area-based marketing (van Tuijl and Otgaar 2016).

As the owner of the buildings at RDM, the Port of Rotterdam Authority developed the site (Hooijer and Muris 2010). A group of architectural historians based in Rotterdam (Crimson) conducted a detailed historical and cultural study of the RDM terrain 
to clarify the heritage value of the buildings and other historical elements, commissioned by the Stadshavens development company in collaboration with Urban Planning + Housing/Spatial Development/Monuments Rotterdam and Netherlands Department for Conservation. ${ }^{1}$ In addition, a detailed historical orientation study was requested for the renovation of each building. Some of the buildings on RDM site were already in the process of becoming a registered national monument. However, the municipality of Rotterdam and the Port of Rotterdam made a gentlemen's agreement to hold the nomination until after the redevelopment and renovation of the site: the developer (the Port) would get more freedom and authority, and it would carefully handle redevelopment with respect to the historical value of the site and the buildings. The Port of Rotterdam started to work on a master plan and business model for the campus.

The educational institutions moved into the renovated central machine hall and the former head office of RDM (now stands for Research, Design \& Manufacturing) in 2009. The campus became a place where students and companies collaborated in an open environment and focused on new economic activity and sustainable and innovative solutions in subjects like manufacturing, building and maritime. In the opening ceremony after the development of new office area named as "RDM Innovation Dock", the developers opened the "blue gate", once the main entrance for RDM workers, to local residents; this ritual welcomed them to the site that had been closed to them for so many years. The village of Heijplaat benefited from the renovation, gaining public space, improved access to the waterfront and public transport (a water bus) to the city centre. Residents could eat at the new Dock Café in RDM's former staff canteen (Vries 2014).

The redevelopment of the RDM site was the result of a lucky coincidence: the distinctive site became available and port authorities were looking for a new tenant just as educational establishments had a real need for additional space. Then, the port authority used its traditional funding model to carry out the project: As the landowner and port manager, it actively searched for tenants; after they signed long-term contracts, the port authority renovated the halls according to the wishes of the clients; then, it used the income from the long-term contracts fund further development. In addition, it offered tenants empty plots on the RDM site for new construction. Even though this is a traditional model for the Port Authority, it was a new approach for area development, which normally works with a strict master plan that has been prefinanced with large investments. The Port Authority's approach was more flexible and included less financial risk (van Leeuwen 2013).

\footnotetext{
${ }^{1}$ Rijksdienst voor de Monumentenzorg.
} 


\section{World Port Days: A Tool for Reinventing Maritime Culture During the Transformation of the Port-City}

On the first weekend of September, Rotterdam celebrates its maritime culture and identity during World Port Days, with the harbour as the epicentre of the party. It is Europe's largest port-city festival, attracting thousands of visitors, and it has been happening every year since 1978. Although downtown Rotterdam is no longer a seaport area, it still hosts several maritime and municipal institutions and companies, both local and global.

Looking at the number of visitors and the nautical organizations participating in this event, we can discern its socio-economic benefits (Otgaar et al. 2016, 169). The World Port Days seem to be a prominent podium and an excellent opportunity for bringing public attention to the value of vital interconnection between the port and the city.

During the World Port Days, Rotterdam's maritime identity becomes apparent not just as a folkloric leftover but also as the primary basis for current social and economic development (Van der Berg and Tuij 2016, 218-220). There, the local community and guests gather together and enjoy various activities-ship tours, naval activities, demonstrations, seminars, excursions, exhibitions, music and much more.

\section{Conclusion}

Like many port cities across the world, "Rotterdam is looking for ways to reproduce its water-related heritage values to build a responsive, resilient, and competitive portcity relationship". (Stadsvisie Rotterdam 2030 2007). In recent decades, the City of Rotterdam has invested millions of euros to empower the maritime heritage of this famous port city, funding new projects to restore and renovate historic waterfronts, boats, and port infrastructure and to organize related festivals, seminars, and events. The modernization of the Cruise terminal, the annual World Port Days, and the revitalization of Stadshaven — including the redevelopment of the RDM-all shared one goal: reinvention of the links between the port and the city and revitalization of the faded image of port in urban spaces.

Recently, some urban scholars have pointed out the importance of a dynamic maritime identity and water-related heritage values to historic port cities, and have identified the role of a vital port city interconnection in urban renewal and the redevelopment of urban areas because of rapid urban change and socioeconomic makeovers (Warsewa 2011; Dell' Acqua and Wegman 2017, 667).

Each port city needs to consider more wide-ranging approaches for sustainable development, which includes their maritime identity past and present. The redevelopment of the Rotterdam waterfront and the revaluation of its heritage have evolved significantly during the last decade. A Unit Approach, with an integrational perspective and a grand blueprint with governmental financial support, as in the Kop 
van Zuid project, was replaced by a Chain Approach, a more pluralist view with a public-private partnership within a governance context, as in the RDM Campus project.

But the future trajectory in the Makers Space area breaks with the past and is based on empowering local communities and carrying out the long-term vision on a small scale. The steering will be done by a small unit (Rotterdam CityPorts), a facilitator and a connector between existing and future developers and entrepreneurs. The strategy is shifting towards a flexible, network-based strategy and a more private engagement in development of the coming phases of this project. With its public-private cooperation strategy for the Makers Space, Rotterdam's Stadshavens has created a clear pathway for the redevelopment of the area: promising to be socially inclusive, connect the city to the ports, and create a lively mixed-use area. The new flexible approach in dealing with waterfront redevelopments in Rotterdam considers the use of the places, and the story behind them, more significant than the built environment. At RDM, the planners retained the physical aspects of the buildings and the area to the extent that they can tell their story in the future. They did not aim to make the area attractive or turn it into a museum, but instead highlighted its industrial legacy and its relation to water. The new approach uses local identity and well-known local names and brands to attract more businesses and innovative industries to the area.

This new flexible approach allows for a wide range of users and private investors to invest in the development of this area. However, the risks and opportunities for the private sector are not very clear in this flexible framework. This creates a lot of uncertainty for potential investors and private developers. So, as more new entities and private sectors get involved in the development of the area, adequate control by the monument committee and other heritage bodies within the municipality is becoming necessary. It will also be necessary to make the tools and regulations more clear within this new flexible approach.

\section{References}

Aarts M, Daamen T, Huijs M, de Vries W (2012) Port-city development in Rotterdam: a true love story. http://urban-e.aq.upm.es/. Rotterdam, 2013

Alegret J et al (2014) Revisiting the coast: new practices in maritime heritage. Documenta Universitaria, 2012

Assmann J, Czaplicka J (1995) Collective memory and cultural identity. New Ger Crit 65:125-133. https://doi.org/10.2307/488538

Boelens L (2009) The urban connections, an actor relational approach to Urban planning, vol 62. NAI

Bone K, Bone E, Betts MB (1997) The New York waterfront: evolution and building culture of the port and harbor. Monacelli, New York

Breen A, Rigby D (1996) The new waterfront: a worldwide urban success story. Thames and Hudson, London

Brown PH (2009) America's waterfront revival. Port authorities and urban redevelopment. University of Philadelphia Press, Philadelphia

Crimson (2005) Cultuurhistorische verkenning van de RDM 
Daamen T (2010) Strategy as force, towards effective strategies for urban development projects: the case of rotterdam city ports. Ph.D. Delft University of Technology

de Goey F et al (2004) Comparative port history of Rotterdam and Antwerp (1880-2000). Aksant

Dell' Acqua G, Wegman F (2017, April 10-12) Transport infrastructure and systems: proceedings of the AIIT international congress on transport infrastructure and systems. Rome, Italy, p. 667

Desfor G, Laidley J, Schubert D, Stevens Q (eds) (2010) Transforming urban waterfronts: fixity and flow. Routledge, London

Ducruet C, Notteboom T, Langen P (2009) Revisiting inter-port relationships under the new economic geography research framework. Ash gate. In: Ports in proximity: competition and coordination among adjacent seaports, Ashgate, pp 11-27

Dündar S et al (2014) New faces of harbour cities. Cambridge Scholars Publishing

Feyen J et al (2008) Water and urban development paradigms: towards an integration of engineering, design and management approaches. CRC Press

Hein C (2011) Port cities: dynamic landscape and global networks. Routledge, New York

Hein C (2016) Port cities and urban waterfronts: how localized planning ignores water as a connector. WIREs Water 3:419-438. https://doi.org/10.1002/wat2.1141

Hein C, Hillmann F (2016) The missing link: redevelopment of the urban waterfront as a function of cruise ship tourism. In: Porfyriou H, Sepe M (eds) Waterfronts revisited. Routledge

Hooijer B, Muris G (2010) RDM campus: an innovative learning and working environment in the port of Rotterdam

Hoyle BS (2000) Global and local change on the port-city waterfront. Geogr Rev 90(3):395-417

Hoyle BS, Pinder D, Husain MS (1994) Revitalising the waterfront: international dimensions of Dockland redevelopment. Wiley, Chichester

Jinliang Q (2012) Protecting China's maritime heritage: current conditions and national policy. J Mar I Cult 2212-6821

Lee R (1998) The socio-economic and demographic characteristics of port cities: a typology for comparative analysis? Urban Hist 25(02):147-172

Mah A (2014) Port cities and global legacies, urban identity, waterfront work, and radicalism. Springer

Mak A, Stouten P (2014) Urban regeneration in Rotterdam; economic and social values. Eur Spat Res Policy 21(1). https://doi.org/10.2478/esrp-2014-0008

Marshall R (ed) (2001) Waterfronts in post-industrial cities. Spon, London

Meyer H (1996) City and port transformation of port cities. London, Barcelona, New York and Rotterdam NAI

Ministry of Economy (2009) Economische visie op lange termijn de mainport Rotterdam

Norcliffe G, Basset K, Hoare T (1996) The emergence of postmodernism on the urban waterfront. J Transp Geogr 4(2):123-134

OECD, Merk O (ed) (2014) The competitiveness of global port-cities: synthesis report. Available at https://www.oecd.org/cfe/regional-policy/Competitiveness-of-Global-Port-CitiesSynthesis-Report.pdf

OMSR (2005) Stadshavens Rotterdam Ontwikkelingsstrategie-concept. OMSR, Rotterdam

Otgaar A et al (2016) Industrial tourism: opportunities for city and enterprise. Routledge, Prologue

Pleßka N (2014) The intelligible metropolis: urban mentality in contemporary London Novels. Transcript Verlag

Schipper (2010) BC AD (English edition). Benthem Crouwel 1979-2009. 010 Publisher

Schubert D (1994) Zwischen Wasser und Land: Neue Entwicklungen in alten Häfen. In: Deutsche bauzeitung, Jg. 128(11): 50-56

Schubert D (2009) Ever-changing waterfronts: urban development and transformation processes in ports and waterfront zones in Singapore, Hong Kong and Shanghai. In: Graf A, Huat CB (eds) Port cities in Asia and Europe. Routledge, London

Smith, HD, de Vivero, JLS, Agardy TS (2015) Handbook of ocean resources and management. Routledge, p 414 
Smith H, Ferrari MSG (eds) (2012) Waterfront regeneration. Experiences in city-building. Routledge, London

Stadsvisie Rotterdam 2030, publication of the City of Rotterdam (2007)

Steenhuis-Meurs (2009) Spangen-Rotterdam, cultuurhistorische verkenning. Available at www. rotterdam.nl

Stocker L, Kennedy D (2009) Cultural models of the coast in Australia: toward sustainability. Coast Manag 37(5):387-404

Stouten P (2010) Changing contexts in urban regeneration: 30 years of modernisation in Rotterdam. Techne Press

Structuurvisie Stadshavens Rotterdam, the city of Rotterdam. Sept 2011

Van der Berg L, van Tuij E (2016) Urban festivals as tools for social development, the case of world port days in Rotterdam. In: Nel-lo Oriol, Mele Renata, 2016. Cities in the 21st Century. Routledge

van Leeuwen M (2013) Gebiedsontwikkeling nieuwe stijl standaard voor RDM Heijplaat. vastgoedmarkt

van Tuijl E, Otgaar A (2016) RDM campus. In: Carvalho, L, Van Den Berg L, Galal H, Teunisse P (eds) Delivering sustainable competitiveness: revisiting the organising capacity of cities. Taylor and Francis

Vries IMJ (2014) From shipyard to Brainyard the redevelopment of RDM as an example of a contemporary port-city relationship. In: Alix et al (eds) Port-city governance, pp 107-126

Ward SV (2006) Cities are fun: inventing and spreading the Baltimore model of cultural urbanism. In: Monclús FJ, Guardia M (eds) Culture, urbanism and planning. Ashgate, Aldershot

Warsewa G (2011) Adaption and individuality, the reinvention of the port city. In: Häyrynen S et al (eds) Locality, memory, reconstruction: the cultural challenges and possibilities of former single-industry communities. Cambridge Scholars Publishing

Wigmans G (1998) De facilitaire stad: Rotterdams grondbeleid en postmodernisering. Delft University Press, Delft

Winslow C (1998) Waterfront workers: new perspectives on race and class. University of Illinois Press

Azadeh Arjomand Kermani is a postdoctoral researcher at the Chair of Heritage \& Values at Delft University of Technology. Her dissertation explored urban design of the historical built environment, focusing on Iran. Her research interests include the impact of planning policies and governance on the management of both tangible and intangible heritage.

Wout van der Toorn Vrijthoff is emeritus associate professor in real estate management and development at Delft University of Technology. His publications include the book More Urban Water: Design and Management of Dutch Water Cities. He is currently working with colleagues from other European universities on heritage planning projects.

Arash Salek is an urban-regional development advisor for the City of Rotterdam. He has also been a policy advisor in heritage and urban history. His background is in architecture, urban history and metropolitan development; his work examines the regeneration of post-harbour urban areas. 
Open Access This chapter is licensed under the terms of the Creative Commons AttributionNonCommercial-NoDerivatives 4.0 International License (http://creativecommons.org/licenses/bync-nd/4.0/), which permits any noncommercial use, sharing, distribution and reproduction in any medium or format, as long as you give appropriate credit to the original author(s) and the source, provide a link to the Creative Commons license and indicate if you modified the licensed material. You do not have permission under this license to share adapted material derived from this chapter or parts of it.

The images or other third party material in this chapter are included in the chapter's Creative Commons license, unless indicated otherwise in a credit line to the material. If material is not included in the chapter's Creative Commons license and your intended use is not permitted by statutory regulation or exceeds the permitted use, you will need to obtain permission directly from the copyright holder.

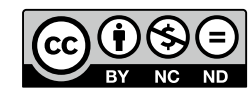

